\title{
Chapter 3 \\ Everybody on Board? Opportunity Structures for Social Innovations in Münster
}

\author{
Christina Rentzsch
}

\subsection{Introduction}

In 2004, Münster received the international LivCom Award acknowledging the town as the Most Liveable City in the World. ${ }^{1}$ Since then, the city has merchandised this image within and beyond the region (Hauff and Heineberg 2011; p. 5). The middle-sized town of Münster with its around 300,000 inhabitants is a flourishing city: immigration surpasses emigration, the large administrative and academic sectors provide employment opportunities for the well educated, and the overall eight universities and their approximately 50,000 students buffer demographic change. Simultaneously, the prosperous socio-economic situation of Münster is enveloped by a conservative-Catholic culture, emphasizing solidarity with weaker members of the society and referring to subsidiarity as a key policy principle.

This chapter addresses the questions of how social innovations emerge in Münster and how they are embedded within the city's governance arrangement. The analysis focuses on two major policy fields best reflecting Münster's specific governance arrangement: labour market and housing policy. ${ }^{2}$ After an overview of administrative structures in Germany and specific city traditions (Sect. 3.2), the chapter

\footnotetext{
${ }^{1}$ The following article is based on research carried out as a part of the WILCO project from 2011 until 2014 in Münster. The author is very grateful to Patrick Boadu, Danielle Gluns, Thorsten Hallmann and Andrea Walter.

${ }^{2}$ The study and its data collection — conducted over the course of 4 years (2007-2011) — consisted of the following elements: interviews with politicians, administrative employees and civil society organizations at the local level; a detailed analysis of documents produced by the city council and the council's committees; an analysis of major articles of the leading local newspapers on selected issues, and for labor market policy an additional local magazine; several focus group interviews; as well as an analysis of the election programs of all relevant parties for the local elections in 2004 and 2009.
}

\section{Rentzsch ( $\square)$}

Institute of Political Science, Westfälische Wilhelms-Universität Münster,

Scharnhorststraße 100, 48151 Münster, Germany

e-mail: christina.rentzsch@uni-muenster.de

(C) The Author(s) 2016

T. Brandsen et al. (eds.), Social Innovations in the Urban Context,

Nonprofit and Civil Society Studies, DOI 10.1007/978-3-319-21551-8_3 
analyses Münster's governance arrangement (Sect. 3.3) and addresses the topic of who makes things happen in the city in terms of coalition building. There is a strong focus on the interdependence between governance and social policy discourses. Despite some caveats, Münster is a city whose administration is inclined to open windows of opportunities for the implementation of social innovations (Chap. 4).

\subsection{Münster's Embeddedness in Germany's Governance Arrangement}

\subsubsection{Cooperative Federalism, Self-government and Subsidiarity}

In international comparisons, Germany stands out for a specific type of federalism: Sixteen states (Länder) are bound together by "co-operative federalism" (Scharpf 1976), a multilevel governance arrangement of interrelations between the federal, regional and local level, in which responsibilities are divided according to tasks and policy fields. Thus, German municipalities are not independent administrative units but embedded in a system of administrative regulations, inaugurated by the Länder and the federal government. Simultaneously, German municipalities look back upon a long tradition of self-government. Elections to the local parliament take place every 5 years, and local politicians enjoy a certain leeway of how policies are enacted. Albeit in close cooperation with the local administration, local parliaments guarantee the participation of citizens in local politics (Bogumil and Holtkamp 2006).

Furthermore, Germany is particularly noteworthy for neo-corporatist governance arrangements (Schmitter 1974), in which civil society organizations and associations (Verbände) traditionally play a key role in the policy process, bridging the different territorial levels (local, subnational and federal) of the country (Zimmer et al. 2009). Legitimated by the principle of subsidiary neo-corporatism at the local level translates into a situation in which civil society organizations or nonprofit organizations (NPOs) are the prime providers of social services (Dahme and Wohlfahrt 2011; Evers et al. 2011a).

\subsubsection{Münster: Desk of Westphalia-City Profile}

Situated close to the Ruhr area of Germany, Münster has never been an industrial town, characterized by an entrepreneurial spirit and a governing elite of internationally oriented businessmen. Instead, in the nineteenth century, the town became the host of a Prussian Military Base and developed into a stronghold of the Prussian Provincial Government. Today, the legacy of history is still strongly in place. There 
are numerous public and semi-public administrative units operating in Münster, such as the Regional Government or the Pension Insurance Institute for WestphaliaLippe, a sub-district of the region of North Rhine-Westphalia. Until very recently, the British Rhine Army had their headquarters in Münster. Today, it only hosts the German Netherlands Corps, and soldiers no longer impact the culture of the city.

Against this background, Münster enjoys the image of being the "Desk of Westphalia" (cf. Heineberg 2011; p. 268), a city in which blue-collar workers are more or less absent and where civil servants play a decisive role in city politics. The presence of numerous institutions of higher education such as Münster University, Münster Polytech, the University for Public Administration or the University for the Police adds to the picture of a city dominated by middle-class inhabitants, most of them being civil servants. All in all, the public sector constitutes the most important economic force in the city. Public sector dominance is hardly balanced by a class of merchants who similar to other traditional European cities and former trading posts today still run their shops in the centre of the picturesque medieval old town that constitutes the prime tourists attraction in Münster.

Besides its long tradition dating back to the Middle Ages and times of the former Hanse and its middle class, civil servant population, Münster is famous for being a stronghold of Catholicism in the North of Germany. Indeed, Münster used to be the centre of the Catholic counter-revolution at the beginning of the nineteenth century. The famous Graf von Galen, who raised his voice against the rule of Hitler in the 1930s, served as Archbishop in Münster. Since the late nineteenth century, Münster has been a stronghold of political Catholicism, in particular the Zentrum Party during the German Empire and the Weimar Republic, and the German Christian Democratic Party after 1945.

\subsubsection{Winds of Change}

The legacy of Roman Catholicism, the impact of the surrounding rural area of Westphalia and the dominance of civil servants led the Christian Democratic Party to be the most important political force in the city. However, since the 1990s, new political forces, the Green Party and the Linke, have significantly challenged the conservative milieu of the city. Both were able to build constituencies within the post-materialist academic milieu in Münster.

In the 1990s, for the first time in Münster's political history, the Christian Democrats were not in power for one electoral term. Since then, the Mayor has been a Christian Democrat again. However, the directly elected conservative Mayor does no longer enjoy a comfortable majority in the city parliament; instead, he has to govern with shifting majorities of which a so-called clandestine coalition with the Social Democrats turned out to be the most stable government arrangement. The grand coalition in disguise reached its peak during the late 1990s and the early 2000s, a period in which Münster embarked on a new approach of city development that slightly departed from classical neo-corporatism. Besides traditional civil soci- 
ety players, a broad spectrum of groups and constituencies were addressed and welcomed to participate in a long-term consultancy process. The outcome was a master plan for city development, closely combining city development and city marketing. ${ }^{3}$

The master plan highlights the necessity of becoming a city attractive for investments from local and regional business communities. For the first time in Münster's post-war history, city development became a central issue based on a strategic plan for long-term investments and projects. Besides its novelty, however, the master plan also links up with Münster's tradition as a middle-sized town and European city looking back to a subsidiary tradition of taking care for constituencies in the community who need help and public support. From an institutional point of view, the master plan encompassed the establishment of a new unit within the town hall, "Münster Marketing". Münster Marketing is an independent organization hosted by the city administration and hence located in the town hall. Since its foundation in the early 2000s, Münster Marketing has developed into a very influential player within the city. Like "a spider in a net", the chairwoman of Münster Marketing is highly connected and therefore able to monitor any development within the city. The central task of Münster Marketing is to get relevant stakeholders around the table whenever a new initiative or a new project is about to start and inaugurated in Münster. Due to its peculiar organizational setup, Münster Marketing enjoys excellent contacts within the city's administration, the political sphere and the local business community. As such, Münster Marketing constitutes an institutionalized symbol for the Münster-specific "governance of co-operation".

\subsection{Münster's "Governance of Cooperation"}

As outlined in the previous chapter (Cattacin and Zimmer 2015), governance of cooperation is characterized by the continuous search for synergies between economic and social policies. Although the search for investments constitutes the driving force of city politics, actors in Münster are sensible not to lose contact with the social domain. The underlying rational of action is pragmatism combined with efficiency. Actors in the city search for practical solutions for today's problems without giving up an investment-focused policy orientation. As outlined in the following section on "innovations" in the areas of housing and labour market policies, there seems to be a division of labour with regard to economic and social policies. Social policy is by and large considered to be the prime responsibility of public and hence the city's administration, while business issues are primarily taken care of by the business community. Moreover, Münster's governance of cooperation is inclined to empower citizens in order to make them fit for the market and hence to be able to help themselves.

\footnotetext{
${ }^{3}$ Stadt Münster 2004: Integriertes Stadtentwicklungs- und Stadtmarketingkonzept Münster (ISM) Münster-Profil, Leitorientierungen und Leitprojekte. (http://www.muenster.de/stadt/stadtplanung/ pdf/Vorl118_04_und_Erg.pdf).
} 
This attitude is very much in line with the subsidiarity tradition of Münster in the welfare area. Overall, Münster's governance of cooperation tries to follow an encompassing approach of bringing people with similar problems together in order to work out most practical solutions. The city continuously attempts to balance its investment orientation of the city, taken up in the late 1990s and working with the paradigm of the city as "a growth machine". It refers to a "preventing frame" that is highly supported by representatives of the political parties, members of the city administration and civil society actors, including members of the local clergy. In the following, this chapter will first focus on the investment frame, which is linked to the "growth machine" paradigm; in the second step, this frame will be juxtaposed in opposition to the "prevention frame" of Münster's cooperative governance coalition (the following chapter is based on WILCO report 4, Boadu et al. 2012).

\subsubsection{Münster as "Growth Machine": The Investment Frame}

The "deep core" of the local coalition system is a frame of municipal management that invests all its resources in improving the city's capacity for enhancing local (economic) growth and growth sustainment. Moreover, growth is perceived as the main factor for the wellbeing of citizens and for the city development. The frame originates from the theoretical premises described by Harvey Molotch in "The City as a Growth Machine" (Molotch 1976), which argues that growth should be an essential imperative. The central conditions for growth are defined as follows:

1. A high level of competitiveness for companies and citizens with other cities, achievable through the improvement of both hard and soft site factors

2. A high level of attractiveness attained by means of city branding or marketing with a focus on high quality of life and a special lifestyle, as well as a "festivalization" of city policies: the concentration on highly marketable, prestige projects and actions (Häußermann and Siebel 1993)

3. An approach to city management that creates a market-friendly environment, thus making the city a viable target for private investment and enabling its effects to benefit the whole community

Since Münster fits these criteria perfectly, it presents a good example of "the city as growth machine". This general orientation significantly influenced local discourse and translated into the establishment of an investment frame widely considered a success story in Münster. Over the years, it has gained increasing acceptance by a broad coalition of different actors, resulting in a relative stability of the frame since the early 1990s. It continues to be perpetuated by political subsystems in Münster within a wider coalition system. Apart from superficial modifications in rhetoric and action, the frame remains stable. "Münster Marketing", the "Initiative for a Strong Inner City", a lobby group of Münster's merchants, the traditional guild of merchants "Kaufmannschaft" and of course the municipal department for the promotion of the local economy (Wirtschaftsförderung) support the investment frame. 
However, in the welfare domain, it is counterbalanced and complemented by a very different frame, which originates in the subsidiarity tradition of the city.

\subsubsection{Münster a City Based on Subsidiarity: The "Prevention Frame"}

"We should be careful and avoid that people, kids included, are faced with difficult situations in their lives. Instead of simply letting things happen, we should be preventive and start to empower people as early as possible", the chairwoman of the Children and Youth Department of Münster stated in one of our interviews. The quote nicely encompasses the central idea of policy action before a significant problem comes to the fore. The idea of avoiding problems by providing citizens with tools and skills to help themselves is embedded in both political traditions most prominently influencing politics in Münster, Social Democracy and Christian Democracy, influenced by subsidiarity. Interviews conducted under the framework of the Welfare Innovations at the Local Level in Favour of Cohesion (WILCO) project showed that the empowerment argument of the prevention frame was primarily referred to by members or representatives of the Social Democratic Party (SDP) in Münster. Their reference to the prevention frame was linked to considerations of equality, life changes and justice. Representatives of the Christian Democratic Party also turned to the prevention frame, in particular to legitimize social policies.

However, the underlying rationale they referred to it was quite different. In a nutshell, they pointed to a cost argument, claiming that it is cheaper to invest in prevention now than to have to pay more for removal of the damage. Hence, a somehow economic logic is also inherent to the prevention frame. In Münster, the prevention frame is referred to in various social policy fields, surpassing the classic welfare or social policy toolbox. Under the Leitmotiv of the prevention frame, policy measures aim to ensure that all groups and individuals are empowered to participate as successfully as possible in the market. Hence, the two dominant policy frames in Münster counterbalance each other. However, at the same time there is a slight bias in favour of the investment frame because prevention policies might also be inaugurated and put in place using the vocabulary of the investment frame.

\subsubsection{The Policy Coalition}

As indicated earlier, Münster is a very homogeneous city. Results of the WILCO project highlight that poverty and unemployment are not significant issues in Münster. Furthermore, the city counts among the very few in the region of North-Rhine Westphalia with a growing population. The number of unemployed citizens is below the country's average rate of unemployment. The same holds true for the number of migrants. Indeed, the population with a migration background is very 
limited in Münster. Furthermore, due to the attractiveness of the University, many citizens with migration background came to Münster in order to study. They stayed and started professional careers. Since big business is almost absent in Münster, homogeneity constitutes a characteristic feature of the city. Furthermore, some business entities are indeed semi-public institutions, such as a quite influential saving bank or a major insurance company. Against this background, it does not come as a surprise that numerous circles and semi-public initiatives in Münster are serving as forums for discussion and policy deliberation. There is also significant overlap between the different groups and round tables that constitute a semi-public discursive sphere in the city.

In summary, Münster is run and governed by a relatively small circle of engaged citizens, members of the city administration and representatives of merchants, civil society organizations and the two churches. The closeness of Münster's elite circles has been the subject of various studies (Termeer 2010; Schwalb 2011; Paulsen 2015) that unanimously testified to the significant importance of the city or municipal administration. The important role of the administration has been further strengthened in recent years due to the fact that the Mayor, simultaneously head of the city government and chairman of the municipal administration, is directly elected by the local population and therefore enjoys a significant legitimacy.

However, homogeneity and a culture of making politics in small circles also have flip sides. As a newcomer, it is not easy to get access to those circles in the city where "fat cats keep in touch". Indeed, homogeneity with respect to gender, class and, in particular, age was also the most significant characteristic of members of the respective policy coalitions identified under the framework of the WILCO project. During the time of the investigation, individuals mostly ran the city in their late 50s or mid-60s, irrespective of their background (political parties, business community or local administration). In summary, this generation shares the same ideas and concepts. It is tied together by a common culture of a time when Germany started to emancipate itself from the post-war period. It is also this very generation that is responsible for the gentrification of the inner cities.

Also, this generation supports a classical divide between economic and social policy. Not surprisingly, the majority of innovations identified in Münster by WIL$\mathrm{CO}$ were initiatives by the municipal administration, implemented through network governance or governance of cooperation between municipal administration and "outsiders", that is members of the respective policy coalition. In order to highlight the decisive role of the city administration for innovations in the area of social policy, two innovations identified in Münster as part of the WILCO project will be portrayed in the following section beginning with a brief outline of the policy fields labour market and housing (The following chapter is based on WILCO report 3, Boadu et al. 2011). 


\subsection{Governance Structures, Discourses and Innovations in Münster's Labour Market and Housing Policy}

\subsubsection{Labour Market Policy in Münster}

Compared to neighbouring regions and Germany in general, the labour market situation in Münster is significantly better. Unemployment is relatively low, even for disadvantaged groups such as migrants and adolescents; the presence of nearly 50,000 students gives employers the possibility to recruit candidates from a vast pool of flexible, young and well-educated people interested in marginal part-time employment. Although Münster is not known for a long philosophy of local labour market policy ${ }^{4}$, a local labour market initiative was founded specifically targeting young adults; Arbeitsmarktinitiative Münster was launched during a social democratic and green party majority about 20 years ago. At that time, a number of youth training centres were started by the city or NPOs, but the conservative majority in Parliament largely reduced public spending on local labour market policies from 1999 onwards. The European Social Fund (ESF) and/or the State of North RhineWestphalia now fund initiatives formerly financed by the municipality. The ESF is an important financial pillar of local labour market projects.

Besides the two major public institutions responsible for labour market policies (Federal Agency for Employment and its local Jobcentres), the third sector and private organizations play a role in the provision of labour market programmes and activities as well (see Evers et al. 2011b/WILCO WP2 County report Germany). In Münster, the welfare associations of the churches are active in the field of labour market policy, that is Caritas and Diakonie, as well as local associations, initiatives and foundations. They offer personal advice and support on site, especially for specific groups of people, such as young adults or refugees ${ }^{5}$.

Additionally, relations between different actors in local labour market policy are institutionalized in the Advisory Board of the Jobcentre, which performs an advisory function for the municipality but does not have any decision-making power. Although this board is a legal requirement, it was given additional weight in Münster, asking various actors to serve on the board with the aim of assessing local labour market policy. The Jobcentre's Advisory Board consists of 16 regional representatives from the field of labour market policy from administration, civil society and political parties; it becomes increasingly involved in the development of local

\footnotetext{
${ }^{4}$ As the parliamentary leader of the Social Democratic Party (SPD) states: "Economic and social policy is not made in Münster's town hall. This can be seen in the mentality of local politics handing over labour market policy to the private sector; the economy that is responsible for creating jobs." Interview with the parliamentary leader of the SDP in Münster.

${ }^{5}$ One prominent example of a civil-society-driven project of collaboration between various actors in the field of employment policy is the MAMBA network, focusing on the qualification of refugees and other migrants with a legalized residency status.
} 
labour market strategies in order to develop innovative approaches for the integration into the job market. ${ }^{6}$

\section{Structural Change: Optionskommune}

In Germany, the Federal Agency for Employment and its Jobcentres, local units taking care of the "hard-to-place" unemployed, is in charge of the implementation of labour market policies. However, the federal government provided an option for local governments to partly take over obligations and duties of the Federal Agency for Employment. Hence, the municipality was offered the possibility to integrate the local Jobcentres into their social service profile. This was decided by competitive process on the basis of careful testing of proposals handed in by the respective communities. Once decided positively, the community was awarded the title Optionskommune, the respective city becomes responsible for placement and job search of long-term unemployed.

The application for becoming Optionskommune was prepared in 2010 by the city administration, in particular by the Department of Social Affairs, without consulting many other constituencies. External expertise was called upon to highlight the advantages of the Optionskommune, but these documents only circulated within the administration. Nevertheless, the local parties supported the application for the Optionskommune because they hoped for a more purposeful, responsible and crosslinked local labour market policy. More purposeful means that in future local administration and policy-makers would deal with city-specific problems and federal funding would be used for different employment measures in Münster. More responsible implies that success or failure of certain measures would be evaluated locally, and that cooperation with subcontracting private or nonprofit partners would become more trusting and binding. Third, a more cross-linked labour market policy means improving the integration of social policy, educational policy, childcare and integration policy.

A municipality that "opts out" entrusts the local level with responsibility for the arrangements of local labour market policy and the allocation of federal funding. The introduction of this model constitutes a compromise between state and federal levels after the significant labour market reforms (the so-called Hartz laws) were approved in 2005. Jobcentres are responsible for payment, profiling and case management of unemployed clients as well as for helping them to access additional services such as childcare or debt counselling. Additionally, in order to increase employability, jobcentres have their own budgets at their disposal to pay providers responsible for the placement of unemployed people.

\section{Labour Market Policy as "Investment in the Future?"}

There is a broad consensus on the need to promote Münster both as part of a region and as a city in order to attract a broader spectrum of investors. This consensus

\footnotetext{
6 "Well, the composition of the advisory board included many different providers of job creation measures, counselling centres, the university, economy and chambers, and the social sector was strongly represented as well." Focus group interview II: District executive director of the Paritätischer Wohlfahrtsverband. Original quotation: Also die Besetzung des Beirates [...] waren ganz viele Beschäftigungsträger, waren Beratungsstellen, waren sicherlich auch Universität, Wirtschaft und also die Kammern, aber der soziale Bereich war relativ stark vertreten.
} 
follows the belief that new jobs will be created if the region can attract more investment and the relocation of companies, and thereby help to overcome unemployment. Münster thus relies on "lighthouse projects" to erase the obsolete image of "Münster as an administration town". In order to achieve this, the instrument of benchmarking has been increasingly applied in the field of labour market policy.

Despite the dominance of the investment frame, several groups in the field of labour market policy follow the prevention frame, arguing that one should "become active before the damage has been done" instead of supporting individual "problematic cases". ${ }^{7}$ Youth unemployment in particular requires a specific focus on prevention, since young people have limited access to the local job market. Youth unemployment (especially during the transition from school to work) is a topic widely discussed in politics - by the administration, local media and in party programmes. Young people are considered to be one of the only groups given continuous care. Moreover, prevention in the sense of furthering education also meets the future demand for skilled employees.

With the transformation to Optionskommune, a shift of responsibilities occurred. Proponents of the Optionskommune highlight the opportunity to play a more active role as a municipality in the field of labour market policy and to tap into the potential offered by the good connections between public and private actors in the city. Building on experience and close networks with local businesses and employers, many local public actors expect to be able to organize more effective and efficient labour market integration to establish better ways of taking care of the unemployed and to achieve a stronger focus on preventative work. However, there remains one caveat. People taking administrative decisions, as one informant states, unfortunately "do not speak the language of the people concerned. Not only do they not know how to address them, they do not speak their language". ${ }^{8}$ Maybe the recently introduced advisory board will be able to break up these traditional lines of actions.

\section{Optionskommune: An Example of Innovative Labour Market Policy}

The Optionskommune follows the concept of subsidiarity, stating that the authority least centralized should handle matters. This concept fits into the overarching structure of the German welfare state and Münster's main paradigms. As an innovative approach, it allows a different perspective on the unemployed: unemployment is not seen as an individual failure but mainly a structural problem. The development towards Optionskommune can be seen as an answer to these structural problems, as it brings social policy and the labour market together. The Optionskommune thus follows an empowerment approach: "We are moving away from taking care of the unemployed on the basis of software tools and towards the individuals and their

\footnotetext{
${ }^{7}$ Interview with the head of the Section for School, Advanced Training, Economy and School, Occupational Qualification. Original quotation: Mehr und mehr bemühe man sich darum, aktiv zu werden "bevor das Kind in den Brunnen gefallen ist".

${ }^{8}$ Focus group interview II: Head of the "House of the Assistance to the Homeless" (Haus der Wohnungslosenhilfe = facility of the Bischof-Hermann-Stiftung for the support of the homeless). Original quotation: Und auch nicht die Sprache [der Betroffenen, C.R.]. Nicht nur Ansprache, auch nicht die Sprache.
} 
histories"9. Essentially, this model follows a decentralized approach: it assumes that if the Jobcentre is a local institution, which relies on local expertise and networks, it will be better situated to take care of the unemployed than the Federal Employment Agency. The Jobcentre allows addressing users in more individualized ways, eventually placing more people in paid labour.

Local authority is also trying to decrease bureaucracy in the Jobcentres for the benefit of clients since it improves the focus on individuals and their specific situations. It also supports the idea of giving caseworkers enough room to make independent decisions in favour of the individuals. Altogether, the Optionskommune offers more freedom to use other more flexible and sustainable instruments in addressing users than the former model.

Even though this innovation is an instrument situated on a metalevel, it provides the context and structural framework for strategic and sustainable social innovations within the local welfare system. It can be considered a basic precondition to pursue integrated local social policy that enables the administration to incorporate labour market policy into their local governance approach. The most challenging goal in this process was to bring together different participants, since they "spoke different languages. People working in social policy and the labour market area used the same words but told different stories. Working together on labour market policy while focusing on the various target groups was not possible in the past [...] Being connected by the opting-out model is very valuable."10

Therefore, the most innovative aspect of Optionskommune is the "chance of social policy and labour market policy in the city welding together". Optionskommune opens up a potentially multipurpose scope for integrated approaches addressing social problems. Splitting funding between several social stakeholders is another positive outcome and a reason why the model seems to be a win-win situation for both the administration and social service providers. However, whether the $O p$ tionskommune Münster will be successful in providing jobs more efficiently will depend heavily on the availability of local networks between the administration and the local labour market.

\footnotetext{
${ }^{9}$ Interview with the head of the Social Department of the municipality. Original quotation: Sie nutzen nun einen anderen Beratungsansatz, der darauf beruht, einen Fall nicht mehr nur auf Basis von Software zu bearbeiten, sondern das Individuum mit ihrer oder seiner Geschichte anzuerkennen.

10 Focus group interview IV, Chief executive of the Paritätischer Wohlfahrtsverband. Original quotation: Man hat verschiedene Sprachen gesprochen. Die Sozial- und die Arbeitsmarktmenschen. Die haben diesel-ben Worte genutzt aber was anderes erzählt. Das gab es früher nicht. Dass man zielgruppenorientiert an der Arbeitsmarktpolitik [gearbeitet hat, C.R.]. [...] Da sind dann auch alle Beteiligten durch die Option organisatorisch gebunden an einem Tisch. Und das ist sehr wertvoll.
} 


\subsubsection{Housing Policy in Münster}

\section{Sexy Münster}

From an investor's point of view, Münster is a highly attractive city. The population is growing and the average income ranks above average - building or buying flats and houses in such a rich, growing city allows for successful businesses. However, what happens to those who are financially less equipped in a city with rent rates similar to those of Munich or Milan? It is becoming increasingly difficult for lowincome inhabitants to find affordable housing in Münster. Therefore, financially disadvantaged people only find flats by chance or among the rare offers of social housing associations. Nevertheless, providing sufficient social housing has not been a major issue for administration and politics in the last 10 years. The number of affordable social housing has significantly declined; new social housing is more expensive than old flats from the 1950s or the 1960s. But even those disappear rapidly as they are being converted into modern condos. Particularly in the centre of town, newly constructed buildings are chic, demonstrating wealth and prosperity. While in Münster's centre flats have undergone large value increases, housing situations in several suburbs are desolate. Gentrification of the city centre and selected investments in some suburbs resulted in a segregation of unemployed and working poor in social hotspots.

Similar to labour market policy, the role of local governments in housing policies is quite limited. Housing has become a key area of business interest in Germany. Policy interference has almost always been exclusively based on indirect policy instruments, mostly incentives through tax benefits decided at federal or regional level of government. Hence, besides investing in government-owned housing stock or selling municipal building sites, the municipality does not enjoy much leeway for policy action. Key responsibility of municipalities in housing policy in Germany is planning in terms of issuing zoning plans instead of building. Nevertheless, similar to other cities, Münster has worked out a strategic document for its housing policy. First initiated in 1993 and subsequently updated, Münster's "Local Action Housing Program" is also the result of a round-table-based process of deliberation. Representatives of various constituencies were involved but the Department of Housing and City Development continues to play the key role. A further key player of municipal housing policy in Münster is Wohn + Stadtbau, a housing association (planning, construction, selling and renting out) which is $100 \%$ owned by the city of Münster. As already indicated, in the area of housing there is a forum of communication, chaired by the Head of the Department of Housing and City Development who is also the official representative of the Mayor. The forum titled "Housing in Münster" was founded in 2004 as an initiative of Münster's administration. The working group exchanges information and provides political consultation, which means it is not in a position to make appeals or decisions for any political measures on housing. Since the group's purpose is to establish trustful working conditions, meetings are not open to the public. 


\section{Hotly Debated-Housing Policy}

Although housing policy was always a topic for Münster's local politics, it is not clear if and to what extent the continuous problems of demand, high prices and growing segregation will become the focus of policy measures in the future. The anticipated problems, as well as the problematic focal points, illustrate the pressing need to address Münster's housing situation, since social division is becoming more and more visible. The city and politics are regarded as having little influence and steering competences in the housing policy field. Nevertheless, some experts in parties and administration recognize the growing pressure in the housing market and stress the necessity to act. This is why they work closely together in order to show that a cooperative governance arrangement exists in housing policy as well.

The well-established coalition system gives the impression of homogeneous opinion. Yet, this coalition is composed of the main agenda-setters, who aim for market provision whenever possible, and the local stakeholders, who propose "prevention strategies". Initially, the coalition sought to start an economic cycle in which the city would become more competitive in the acquisition of private investments in the local (high-end) housing market. The rationale was that this would provide economic growth and wellbeing to the entire community. Additionally, these new investments would raise the overall prestige and attractiveness of the city and spur new investments to keep the cycle going. Based on these assumptions, an important part of the city's self-conception derives from the promotion of a high standard of living and attractive housing options, prominently featured in the city's marketing efforts. Judging from the continuous and detailed coverage of such projects in the local media, larger and smaller urban development projects are of high interest to the local public. But housing and urban development issues are also debated rather fiercely in the city council and in its subcommittee. However, the market does not take responsibility for lower incomes. The dominating belief is that everyone will benefit from this development via "trickle down" effects. ${ }^{11}$

Focus on recent housing debates, which were mostly open to the public, shifted away from initiating growth and development towards a discussion about the effects of a high demand for commodities on the housing situation itself, namely (1) that affordable housing is rare and hard to acquire for socially disadvantaged citizens, (2) that rents (for housing and business) are too high for healthy growth in the sector and (3) the acknowledgement that certain "neglected" neighbourhoods do not share positive growth and development effects. These effects are generally accepted as facts (cf. Breckner 2010; Holm 2011). Nevertheless, some still argue that rising rents are in fact an indicator for the success of the current municipal approach. On the contrary, others say that the municipality is not in a position to effectively influence the situation due to the structural characteristic of the housing field. Other

\footnotetext{
11 "The housing market works by itself because demands are high. For the lower income section we have the city-owned housing association "Wohn + Stadtbau". But also if there is construction for the higher income section, other housing units will become available for the lower section and benefit the market as a whole" (Interview with the chief editor of the Westfälische Nachrichten in Münster).
} 
advocates within the coalition claim that the city would have been able to do more in order to increase affordable housing yet gave up its prospects for action mostly due to budgetary restraints or voluntarily in favour of market provisions:

[...] All important projects in the last years have been investors' decisions. Basically, we did not put a municipal project through since the Municipal Library. Those were projects implemented by private investors or by the Catholic Church, not by the municipality. And I think that is a huge danger in a city with that kind of financial volume. ${ }^{12}$

The housing field also reflects the city's dominant discourse structure: Housing policy is mainly seen as an instrument for growth. The investment frame is again the dominant frame whereas social aspects play a minor role. Because of Münster's political culture, important decision-makers have always been vigilant about prohibiting developments that might seriously endanger the social balance in the city. This argument leads to a request for a more "sustainable" growth (prevention of market failure) and a call for caution about endangering the city's attractiveness through social cleavages. Since it is agreed upon that disrupting the city's social balance should be avoided, the need to improve the situation in already neglected neighbourhoods with reactive measures is relatively undisputed in the political arena and the general public.

In this context, several experts refer to "healthy mixes", understood as a mixture of different social groups inhabiting an area. They assume that if there is no such mix, people will be less likely to identify with their neighbourhood and owners will not invest in the housing stock as it may not pay off. "Sustainable neighbourhood development", a preventative "spatial" social policy, does not seem to be heavily disputed within the city context. A general need for sustainable neighbourhood development, a "healthy mix" of inhabitants and the need for affordable living spaces seem to be widely acknowledged by all actors involved, although the means to reach these goals are not agreed on since they are based on different problem analyses. In consequence, the question of how the lack of affordable housing shall or could be countervailed is clearly the main line of public political dispute in the field. With regard to local political actors, the controversies run along traditional party lines, between investment and social perspectives. The administration's role is criticized since it sides with market proponents, emphasizing that public housing cannot create enough affordable accommodation (Völker 2011). ${ }^{13}$ Local authorities think it is more "useful to support lower income tenants with accommodation allowances." ${ }^{14}$ The strength of the market thus remains the dominant line of argu-

\footnotetext{
${ }^{12}$ Focus group interview I: member of the state parliament of North Rhine-Westphalia for the Christian Democratic Party.

${ }^{13}$ Karin Völker (2011) Wohnraum wird immer teurer-Stadt Münster setzt auf freien Markt. ("Housing space is getting more expensive-The city of Münster bets on the free market"). Westfälische Nachrichten, 16 September. http://www.wn.de/Muensterland/2011/09/Zahl-der-Sozialwohnungen-nimmt-ab-Wohnraum-wird-immer-teurer-Stadt-Muenster-setzt-auf-freien-Markt. Accessed 20 March 2015.

${ }^{14}$ Dr. Winfried Michels, Institute for Settlement and Housing at the Münster University.
} 
ment, which means that members of the administration and other actors remain convinced that "the market works" (cf. Uplawski 2009). ${ }^{15}$

\section{Innovative Housing Policy: Osthuesheide}

Osthuesheide is a neighbourhood consisting of several blocks of apartment buildings. Constructed by a private company, the housing stock was once inhabited by members of the British army. As the apartments were gradually sold to private investors or individual owner-occupiers, a "circular and cumulative process of degradation" 16 started: The low standard attracted mainly tenants and owners with fewer resources and necessary investments were omitted. In consequence, several apartments became uninhabitable; poverty and a high fluctuation of residents have become symptomatic of this area.

The fragmented ownership structure and lack of financial capacities of many owners were identified as the main obstacles for further private investment. Legally, only owners' associations $\left(\mathrm{WEG}^{17}\right)$ are able to make decisions on major investments. Therefore, three associations were formed; two associations decided in favour of investments but the third and largest association lacked a majority.

The administration took on a significant role throughout this process. In the first step, the municipality tried to use social work to counteract the negative housing situation and reputation of Osthuesheide, which resulted in very limited success. Consequently, owners were identified as the main addressees of public efforts: Financial investors should be either forced to invest by majority decision or driven to sell their flats, whereas individual owner-occupiers should be convinced of joining the pro-renovation fraction and be assisted with the financial burden.

The core of the innovation Osthuesheide was the moderated process that followed, initiated by the municipality in two of the associations with a high share of owner-occupiers. The general aim was to foster decisions for renovation without the municipality's further financial engagement. ${ }^{18}$ The municipality developed three financial options to meet the needs of heterogeneous ownership.

Despite this involvement, the direct intervention of the municipality was limited to improving the quality of the surroundings and changing the name of the neighbourhood in order to improve its reputation. The city's initial plan to purchase units was soon considered inappropriate, as owning only a low number of flats would not

\footnotetext{
${ }^{15}$ Klaus Uplawski (2009) Konfrontation in der Wohnungspolitik-Markt funktioniert (nicht) ("Confrontation in housing policy - the market (does not) work(s)"). Member of the Office for Urban Development, Urban and Traffic Planning. Westfälische Nachrichten, 28 May. http://www. wn.de/Muenster/2009/05/Nachrichten-Muenster-Konfrontation-in-der-Wohnungspolitik-Marktfunktioniert-nicht (accessed: 20.03.2015).

16 Title of a public protocol of the city council.

${ }^{17} \mathrm{WEG}=$ Wohnungseigentümergemeinschaften are associations of all owners of an apartment building or a housing estate. In yearly assemblies, they decide upon, for example, renovation/ modernization measures, contributions to a maintenance reserve fund, etc.

18 The aim of the renovation was not only to improve the living situation of existing tenants but also to attract new and well-to-do inhabitants to the area. The common catchphrase "to create a (healthy) social mix" was found with some variations in several council debates, some party programmes and a number of WILCO-related interviews.
} 
generate sufficient influence. There were also concerns that the municipality could be in danger of being legally liable in the event that owners' associations were unable to repay their debts. In order to avoid this, a separate company was founded as a subsidiary of the communally owned Wohn + Stadtbau, "Wohnungsgesellschaft Große Lodden (WGL)". This company was commissioned to buy flats in order to gain a (in the end successful) majority share in the third association, where both the need for investment and the number of flats owned by corporations were highest. The close connection between the established public housing company and the new company allowed obtaining a substantial loan for renovations, since Wohn + Stadtbau offered other houses as guarantees.

Both the moderated process and the renovation in all three associations represent a governance innovation in Münster. Interventions in the ownership structure of neglected neighbourhoods were never executed before, especially not to such a high degree in terms of financial volume. But the representatives of the WGL and the Municipal Office for Housing disagreed about the discursive shift in Münster's local housing policy. According to the representative of the Municipal Office for Housing, a long-term re-communalisation of housing stock is unnecessary. Furthermore, it would suffice to take up an intermediary role, for example, neglected blocks could be bought and resold to private owners based on a contract that included obligations regarding the future development of neighbourhoods. This underlines the predominance of market mechanisms in combination with a certain level of municipal control. This reliance on market mechanisms was only broken up in the "single case Osthuesheide" due to the fact that state and reputation of the neighbourhood was threatening the overarching image of Münster as an attractive location for private investments. This worry activated a broad number of stakeholders and led to the acceptance of public intervention. Most of them consider the Osthuesheide renovation programme as highly successful and sustainable solution to the underlying problems (The following chapter is based on WILCO report 5, Boadu et al. 2013).

\subsection{Windows of Opportunity for Social Innovations in Münster?}

Which factors determine the success of the innovations "Optionskommune" and "Osthuesheide"? Firstly, drivers of the innovations had access to the local "coalition system" and argued in accordance with dominant investment and prevention frames. A network of supporters was easily established. Secondly, the social entrepreneurs who promoted the innovations were members "of the club", the elite network of those representatives of the local parties, the administration and the business community in Münster. Finally, in both cases, in-house lobbying within the local administration proved to be the most efficient path to success. In both cases, 
it was the administration taking action, establishing a network of support and also safeguarding the necessary resources.

Although both innovations proved to be sustainable, their emergence and development was not the result of a democratic process, but heavily backed by a network of the Münster elite instead. Furthermore, both innovations were the results of top-down approaches initiated and put forward by the administration. Hence, one must admit that cooperative governance in Münster is pretty much a "closed shop" affair: homogenous groups of people sharing similar values and ideas what the city should look like and which direction it should develop. These members of the "club" are involved in different areas of social, economic and political life in Münster, a fact that further strengthens the coalition system and turns it into a quite sustainable and powerful governance arrangement. The "coalition" dominates the local discourse to such an extent that anybody who wants to accomplish something must accommodate the distinctive rationales of the investment or prevention frame. Hence, Münster provides a nice case study and textbook example for analysing the discursive turn in policy analysis. There is, indeed, the possibility to become a member of the "club"; however, he or she has to act and more importantly talk and argue in accordance with the discursive hegemony. Therefore, Münster is inclusive because getting people around the table and trying to get as many constituencies involved constitute a traditional trait of the city's governance arrangement, but at the same time, there are a very few "fat cats" in Münster who are continuously in touch and who indeed govern the city.

Also, Münster can be characterized as a city in which the local welfare system is based on a coherent way of addressing social problems, referring to network-based solutions that include various actors of the society. Therefore, Münster does use various opportunities in order to become and stay a successful city - as long as one speaks the language of the dominant coalition.

Considering such a coalition system on the one hand and having a very specific (welfare) tradition in Münster on the other hand, the question arises how new ideas and social innovations can evolve when everything seems to be decided within a somewhat established "closed shop"?

The answer is that, in general, Münster is a city in which social innovations have a good chance of flourishing. However, such innovations only pick up speed in specific contexts. The general welfare frame has profound implications for social innovations since they are context-specific and embedded in a wider social, economic and political context (Moulaert et al. 2005). The context opens the windows of opportunity for social innovators and social entrepreneurs. It establishes the conditions these actors encounter and can thereby promote or inhibit new ideas.

Yet, "context" also means local governance arrangements. Four different dimensions are identified that characterize these kinds of arrangements and that stand for a specific type of urban governance. Münster represents an example of the dimension of "governance of cooperation", characterized by a general orientation towards innovation in politics and economics. Particularly, the search for synergies between economics and social policies to foster the urban character of the city functions as 
a guiding principle. From the organizational point of view, cooperative solutions between all local actors (administration, economy and civil society) are privileged in this search process. All actors involved broadly accept cooperation as the leading principle for city matters, resulting in the approach that "the more allies unite for a specific city matter, the greater the chance to push something through". ${ }^{19}$ This governance arrangement supports the implementation of innovations and allows "another way of cooperative work could be established". ${ }^{20}$

Apart from the overarching logic of the discursive frame and governance arrangements, several other conditions must be fulfilled before social innovations can be implemented or even stimulated. The first condition concerns funding. Original idea and conditions must attract the interest of sponsors in the project. Sponsors have to be market-compliant, which means that they must comply with the lines of argument found in either the investment or the competitiveness discourse. They have to understand that this represents the dominant basis for decision-making. The second condition concerns legitimation, which means that basic legitimation for social innovation is given and accepted by the people involved. Referring to our results from the policy fields we analysed in Münster, an innovation is accepted as legitimate if it is presented within the investment frame. The third condition involves the aspect of appeasement: Any social innovation that challenges the dominant frame will only be supported if the innovators give up some of their resistance against the frame in exchange for financial or advocatory sponsorship. The support granted then serves the appeasement of possible opposition and is considered a win-win situation for all parties involved. Finally, the fourth condition concerns a pragmatic approach towards solving problems at the local level. Social innovations in Münster need to demonstrate a hands-on approach towards perceived problems. This relates to tangible target groups, deprived districts and so on, while more visionary approaches hardly have any chance of success.

The closed-shop mentality, the local welfare discourse with its focus on city growth, local governance arrangements, several conditions that have to be fulfilled to introduce social innovations as well as specific characteristics of local labour market and housing policies - all these dimensions can be found in Münster and must be considered in order to decide whether the initiation of social innovations is fostered or obstructed within the city. Hence, these dimensions create the context that opens the "windows of opportunities" for concrete social innovators and social entrepreneurs.

Open Access This chapter is distributed under the terms of the Creative Commons AttributionNonCommercial 4.0 International License (http://creativecommons.org/licenses/by-nc/4.0/), which permits any noncommercial use, duplication, adaptation, distribution and reproduction in any medium or format, as long as you give appropriate credit to the original author(s) and the source, a link is provided to the Creative Commons license and any changes made are indicated.

\footnotetext{
${ }^{19}$ Focus group interview II, original quotation: Je mehr Bündnispartner sich zu einer Thematik zusammenschließen, desto eher ist die Chance, Dinge auch durchzusetzen.

${ }^{20}$ Focus group interview III, original quotation: ... aber es ist eine andere Art der Zusammenarbeit [eingezogen]
} 
The images or other third party material in this chapter are included in the work's Creative Commons license, unless indicated otherwise in the credit line; if such material is not included in the work's Creative Commons license and the respective action is not permitted by statutory regulation, users will need to obtain permission from the license holder to duplicate, adapt or reproduce the material.

\section{References}

Boadu, P., Dierschke, T., Ewert, B., Evers, A., Paulsen, F., Wolf, A. C., \& Zimmer, A. (2011). City reports: Labour market, childcare, immigration and housing in Münster and Berlin-Friedrichshain-Kreuzberg. WILCO Publication No. 15. http://www.wilcoproject.eu/wordpress/wpcontent/uploads/WILCO_WP3_Berlin1.pdf. Accessed 15 April 2015.

Boadu, P., Gluns, D., Rentzsch, C., Walter, A., \& Zimmer, A. (2012). Framing local welfare: Analysis of the welfare discourse in Münster. WILCO Publication. http://www.wilcoproject. eu/wp-content/uploads/2014/01/WP4-Münster.pdf. Accessed 15 April 2015.

Boadu, P., Gluns, D., Rentzsch, C., Walter, A., \& Zimmer, A. (2013). Welfare innovations in Münster. WILCO Publication. http://www.wilcoproject.eu/munster-report-innovations. Accessed 15 April 2015.

Bogumil, J., \& Holtkamp, L. (2006). Kommunalpolitik und Kommunalverwaltung. Eine policyorientierte Einführung. Wiesbaden: VS Verlag.

Breckner, I. (2010). Gentrifizierung im 21. Jahrhundert. APuZ-Aus Politik- und Zeitgeschehen (p. 17). Bonn: Bundeszentrale für politische Bildung.

Dahme, H.-J., \& Wohlfahrt, N. (Eds.). (2011). Handbuch Kommunale Sozialpolitik. Wiesbaden: VS Verlag.

Evers, A., Heinze, R. G., \& Olk, T. (Eds.). (2011a). Handbuch soziale Dienste. Wiesbaden: VS Verlag.

Evers, A., Ewert, B., Meißner, M., Wolf, A. C., \& Zimmer, A. (2011b). Local welfare systems as part of the German Welfare State: Housing, employment and childcare. WILCO Publication No. 08. http://www.wilcoproject.eu/public/assets/img/uploads/WILCO_WP2_report_08_ DE.pdf. Accessed 15 April 2015.

Hauff, T., \& Heineberg, H. (Eds.). (2011). Städte und Gemeinden in Westfalen. Münster. Stadtentwicklung zwischen Herausforderungen und Zukunftsperspektiven. Münster: Aschendorff Verlag.

Häußermann, H., \& Siebel, W. (1993). Die Politik der Festivalisierung und die Festivalisierung der Politik. In W. Siebel (Ed.), Festivalisierung der Stadtpolitik: Stadtentwicklung durch große Projekte. Opladen: Westdeutscher Verlag.

Heineberg, H. (2011). Münster-vom traditionsreichen "Schreibtisch Westfalens" zur modernen Dienstleistungsmetropole. In T. Hauff \& H. Heineberg (Eds.), Städte und Gemeinden in Westfalen. Münster. Stadtentwicklung zwischen Herausforderungen und Zukunftsperspektiven.

Holm, A. (2011). Wohnung als Ware. Zur Ökonomie und Politik der Wohnungsversorgung. Widersprüche, 121(31), 9-20. (Verlag Westfälisches Dampfboot).

Molotch, H. (1976). The city as a growth machine: Toward a political economy of place. The American Journal of Sociology, 82(2), 309-332.

Moulaert, F., Martinelli, F., Swyngedouw, E., \& González, S. (2005). Towards alternative model(s) of local Innovation. Urban Studies, 42(11), 1969-1990.

Paulsen, F. (2015). Innovative institutionalizations of new forms of governance in urban development Policy in Germany and in the U.S. Westfälische-Wilhelms-Universität Münster: doctoral thesis.

Scharpf, F. W. (1976). Politikverflechtung. Theorie und Empirie des kooperativen Föderalismus in der Bundesrepublik. Kronberg/Ts: Scriptor Verlag.

Schmitter, P. (1974). Still the century of corporatism. The Review of Politics, 36, 85-131. 
Schwalb, L. (2011). Kreative Governance? Public Private Partnerships in der lokalpolitischen Steuerung. Wiesbaden: VS Verlag.

Termeer, M. (2010). Münster als Marke. Die "lebenswertestes Stadt der Welt", die Ökonomie der Symbole und ihre Vorgeschichte. Münster: Westfälisches Dampfboot.

Uplawski, K. (2009). Konfrontation in der Wohnungspolitik-Markt funktioniert (nicht) ("Confrontation in housing policy—-the market (does not) work(s)"). Westfälische Nachrichten, 28 May.

Völker, K. (2011). Wohnraum wird immer teurer-Stadt Münster setzt auf freien Markt. ("Housing space is getting more expensive-The city of Münster bets on the free market"). Westfälische Nachrichten, 16 September.

Zimmer, A., Appel, A., Dittrich, C., Lange, C., Sitterman, B., Stallmann, F. \& Kendall, J. (2009). Chapter 2 Germany: On the social policy centrality of the free welfare associations. In Kendall, J. (Ed.), Handbook on third sector policy in Europe: Multi-level processes and organised civil society (pp. 21-42). Aldershot: Edward Elgar. 